\title{
Molecular Skit- Role-play as a Pedagogical Tool for Teaching Molecular Biology as an Under-Graduate Engineering Course
}

\author{
Shivalingsarj V. Desai ${ }^{1}$, Gopalkrishna Joshi ${ }^{2}$, Gururaj Tennalli ${ }^{3}$ and L.R. Patil ${ }^{4}$ \\ ${ }^{1,3,4}$ Department of Biotechnology, KLE Technological University, Hubballi \\ ${ }^{2}$ Department of Computer Science, KLE Technological University, Hubballi \\ 1desaisv@bvb.edu, ${ }^{2}$ ghjoshi@bvb.edu, ${ }^{3}$ lrpatil@bvb.edu, ${ }^{4}$ gururajtennalli@bvb.edu
}

\begin{abstract}
Role-play is an exercise in which the participants assume certain roles of characters, collaboratively create stories and act-out the roles in character on stage. Role-Play is being practiced as a pedagogical approach since years and has been found to be effective in teaching history, economics, social sciences and engineering subjects as well. The present study discusses a similar effort of group role play practiced for teaching Molecular Biology course for under-graduate students of Biotechnology. The purpose of the Role-Play- Molecular Skit was to enhance the temporal and spatial learning of some selected concepts of Molecular Biology course. The topics chosen were relevant to learning and formed the corner-stones of the course. The exercise comprised two phases- technical script writing and acting-out.
\end{abstract}

The concept of story-building model related to the topic along-with the technical aspects was adopted for script writing. The contents of the scripts were reviewed for essential technical features, effectiveness and feasibility for acting-out. This was followed by assigning the roles amongst the group members and acting-out the concepts on stage. Assessment for the activity was based on appropriate rubrics which were mapped to Graduate Attributes, Global outcomes and Performance indicators. A formal written feedback collected from the participants showed that the activity was a new experience, enhanced the understanding of the concept, sensitized their creativity by story building, honed their writing skills and reinforced their confidence of acting on stage. The activity was thus instrumental in enhancing the learning, improving the communication skills and bringing-in a concerted team effort on stage.

Key words: Role-Play, Technical script, Act-out, Communication skills

\section{Introduction:}

\section{A. About Role Play}

Role playing is an active method of learning process wherein the students assume the role of some assumed character and play the role.. The Oxford English Dictionary defines role-play as: "Noun- the acting out of a particular role". Role-playing is being used as a pedagogical approach for many years, predominantly
Shivalingsarj V. Desai

Department of Biotechnology,

KLE Technological University,Hubballi

desaisv@bvb.edu 
in teaching history, sociology, political science, medicine and off late, mathematics, science and technology. disciplines. Role playing helps students to understand the subtle aspects of the subjects and keep the students involved and interested. It helps to integrate the knowledge in action, exploring alternatives, and explore creative approaches for learning. [1].

Utilizing, Role-playing uses the techniques of drama teaching is a holistic teaching method that inculcates the process of critical thinking, instigates emotions and moral values, and informs about factual data. It has been found that role-playing teaching increases the efficacy of the learning experience and makes it more grounded in reality (Pierce \& Middendorf, 2008). In many of the Universities, as part of meeting the Graduate Attributes, the students are encouraged to participate in team-work, demonstrate articulation and leadership traits.A mentor often steers and monitors the progress of the team activities to ensure effective implementation, equitable distribution of workload amongst the students and avoid any possible conflicts [5].

Role Play assumes significance in the context of teaching the complex abstract ideas . Craciun (2010) explored Role Play for teaching the structure of matter and abstract physics phenomena. usefulness in the understanding and teaching of abstract phenomena [3].

\section{B. Significance of Role Play in Molecular Biology Course}

Learning can be sometimes difficult for students where a one-way mode of flow of information from teachers is practiced and institutional pressures such as standardized tests and inflexible curricula push teachers and students into rote exercises.. At times this may lock the communication between teachers and students into rote exercises. This may lead to spiraling withdrawal and alienation on the part of students. In such "passive learning" environments, students tend to mechanically write down the material but rarely reflect on it. In this context, Role-playing assigns students to think, argue, write and/or behave as if they were a particular person in a particular situation $[2,4]$.

\section{Pedagogical Advantages of Role Play}

The dynamic communicative interplay generated through role-playing exercise has a significant pedagogical advantages. The role-playing exercise stimulates students' involvement and enhance the learning environment [9]. Intensive student participation affords unique learning opportunities to students and enhance their communication skills. [6]. By encouraging experimentation, role-playing helps students discover divergent viewpoints and overcome stereotype mod of learning the concepts as they examine subjects from multiple perspectives [8].

\section{Stake holders, Courses and Topics Selected:}

The sample consisted of 48 students of B.E. (Biotechnology) program belonging to IV semester of KLE Society's B.V. Bhoomaraddi College of Engineering and Technology, Hubballi, Karnataka..The course instructor, students performers and student audience were the various stake-holders in the role-play exercise. The learning from the roleplay was presumed to happen at three levels, highest at course instructor, followed by performers and student audience.

The course selected for the role play was Molecular Biology for IV semester (Biotechnology). The students were formed into groups of four members each. The topics for the activity were chosen following interaction with the students in the classroom, considering the interest of the students, ease of performance and relevance. Table 1 shows the topics chosen for the activity and rationale for selecting the topics.

Table 1 Topics Chosen for Role Play and the Rationale for Selection

\begin{tabular}{|c|l|l|}
\hline $\begin{array}{c}\text { Sl. } \\
\text { No. }\end{array}$ & \multicolumn{1}{|c|}{ Topic } & \multicolumn{1}{|c|}{ Rationale and Significance } \\
\hline 1 & $\begin{array}{l}\text { Messelson and Stahl } \\
\text { Experiment }\end{array}$ & $\begin{array}{l}\text { Proved the hypothesis of semi } \\
\text { conservative replication of DNA }\end{array}$ \\
\hline 2 & DNA Replication & $\begin{array}{l}\text { Central to the understanding of } \\
\text { Molecular Biology }\end{array}$ \\
\hline 3 & Tumor Suppressor Genes & $\begin{array}{l}\text { Genes involved in controlling the } \\
\text { cell cycle and preventing cancer }\end{array}$ \\
\hline 4 & $\begin{array}{l}\text { Transcription and its } \\
\text { Inhibition }\end{array}$ & $\begin{array}{l}\text { Part of central dogma of life \& } \\
\text { involved in mechanism of drug }\end{array}$ \\
\hline 5 & DNA Mutations & $\begin{array}{l}\text { Changes in genes leading to } \\
\text { evolution and involved in genetic } \\
\text { diseases }\end{array}$ \\
\hline 6 & Apoptosis & $\begin{array}{l}\text { Programmed cell death \& significant } \\
\text { in processes ranging from } \\
\text { emryogenesis to ageing }\end{array}$ \\
\hline 7 & Lac Operon & $\begin{array}{l}\text { Model for studying } \\
\text { positive gene regulation }\end{array}$ \\
\hline 8 & Griffith's Experiment & $\begin{array}{l}\text { Demonstrated the principle } \\
\text { genetic transformation in bacteria }\end{array}$ \\
\hline 9 & $\begin{array}{l}\text { Avery, McLeod } \\
\text { Experiment }\end{array}$ & $\begin{array}{l}\text { Supported Griffith's experiment and } \\
\text { proved that the transforming factor } \\
\text { was DNA }\end{array}$ \\
\hline 10 & Trp Operon & $\begin{array}{l}\text { Model for studying Repressible } \\
\text { negative regulation of gene }\end{array}$ \\
\hline 11 & $\begin{array}{l}\text { DNA Repair } \\
\text { Mechanism. }\end{array}$ & $\begin{array}{l}\text { Insights into the mechanism of } \\
\text { reversing the DNA damage caused } \\
\text { by mutations }\end{array}$ \\
\hline
\end{tabular}




\section{Methodology:}

The activity was designed into two phases:

1). Character sketch of technical concept and

2). Enacting.

A. Character sketch of technical concept :

1). Technical Sketch:

As part of first phase, the students were made to draft a write-up of the topic assigned. It was designed on the theme of story-building around the concept and gradually introducing the concept to the audience. The characters of the sketch assumed different roles and an approach to elucidate the technical aspects of the topic was done. The draft was reviewed in consultation with the course instructor and modified wherever necessary.

\section{2). Enacting:}

After the character sketches were completed, as part of second phase, acting-out of the script was performed. Role-play participants were ready to move from the realm of written script to the stage of performance, where students engaged in simulated dialogues with each other, working to act-out the concept that matched with their character sketches with the inherent creativity built in the form of play in the light of technical content of the topic [7].

The activity started with the brief introduction and students performing their assigned roles. Each group performed within a time frame. Appropriate costumes and supporting properties like labels and other aids were made use of for effective delivery of the roleplay. The take-away message of the concept was made clear at the end of each performance. Usage of proverbs and sayings in English and vernacular were encouraged to elicit the inherent creativity and effectiveness.

B. Casting the Character- A case-study of DNA Mutations Experiment:

1. One of the group member among the four would be moving on the stage in an unusual way and is showcased as an alien. Upon interrogation by another member he narrates that he was an ordinary man but had become so due to a process called Mutation.

2. The story unveils as he narrates about Mutation . The members would be wearing placards with A, T, G,
C written on both sides.

3. The different types of mutations (Transition, Transversion, Base-pair, Frameshift due to Insertion or deletion, Non-sense ) are demonstrated on the stage with the appropriate changes being made in A,T,G and $\mathrm{C}$ by overturning the placards.

4. The oral briefing the events goes in tandem and finally the play concludes with all members underscoring the significance of mutations as raw material in evolutionary process.

C. Role Play in the context of Outcome Based Education(OBE):

Outcome based education is student centered instruction system which focuses on measuring student performance i.e. outcomes. Outcomes include knowledge skills and attitudes [11]. Graduate attributes form a set of individually assessable outcomes that are the components indicative of the graduate's potential to acquire competence to practise at the appropriate level. Graduate attributes are clear, succinct statements of the expected capability, qualified if necessary by a range indication appropriate to the type of programme.They are exemplars of the attributes expected of graduate from an accredited programme [10]. The present work addressed some of the Graduate attributes defined as shown in Table 2.

Table 2. Graduate Attributes, Global Competencies and Performance Indicators addresses by Role Play Activity

\begin{tabular}{|c|c|c|}
\hline Graduate Attribute (GA) & Global Competence & Performance Indicator \\
\hline $\begin{array}{l}\text { GA1:Engineering } \\
\text { knowledge: Apply the } \\
\text { knowledge of } \\
\text { mathematics, science, } \\
\text { engineering } \\
\text { fundamentals, and an } \\
\text { engineering specialisation } \\
\text { for the solution of complex } \\
\text { engineering problems. }\end{array}$ & $\begin{array}{l}\text { Demonstrate the } \\
\text { competence in basic } \\
\text { sciences }\end{array}$ & $\begin{array}{l}\text { Apply laws of natural } \\
\text { science to an } \\
\text { engineering problem }\end{array}$ \\
\hline $\begin{array}{l}\text { GA 9: Individual and } \\
\text { team work: } \\
\text { Function effectively as } \\
\text { an individual, and as a } \\
\text { member or leader in } \\
\text { diverse teams, and in } \\
\text { multidisciplinary } \\
\text { settings. }\end{array}$ & $\begin{array}{l}\text { Demonstrate an } \\
\text { ability to form a } \\
\text { team and define a } \\
\text { role for each member }\end{array}$ & $\begin{array}{l}\text { Implement the norms } \\
\text { of practice (e.g. rules, } \\
\text { roles, charters, } \\
\text { agendas, etc. } \\
\text { ) of } \\
\text { effective team work, } \\
\text { to accomplish a goal. }\end{array}$ \\
\hline \multirow{2}{*}{$\begin{array}{l}\text { GA 10: } \\
\text { Communication: } \\
\text { Communicate } \\
\text { effectively on complex } \\
\text { engineering activities } \\
\text { with the engineering } \\
\text { community and with th } \\
\text { e society at large, such } \\
\text { as, being able to } \\
\text { comprehend and write } \\
\text { effective reports and } \\
\text { design documentation, } \\
\text { make effective } \\
\text { presentations, and give } \\
\text { and receive clear } \\
\text { instructions }\end{array}$} & $\begin{array}{l}\text { Demonstrate an } \\
\text { ability to comprehend } \\
\text { technical literature } \\
\text { and document } \\
\text { project work. }\end{array}$ & $\begin{array}{l}\text { Create flow } \\
\text { in a } \\
\text { document or } \\
\text { presentation -a } \\
\text { logical progression of } \\
\text { ideas so that the main } \\
\text { point is clear }\end{array}$ \\
\hline & $\begin{array}{l}\text { Demonstrate } \\
\text { competence in } \\
\text { listening, speaking, } \\
\text { and presentation }\end{array}$ & $\begin{array}{l}\text { Deliver effective oral } \\
\text { presentations to } \\
\text { technical and non } \\
\text { technical audiences - }\end{array}$ \\
\hline
\end{tabular}


The character sketching and enacting of the Role Play was assessed according to the Rubrics framed for the purpose.

Table 3 and Table 4 show the Rubrics formed for the assessment of the activity. Table 3 . Rubrics for Assessment:-Technical Sketch

\begin{tabular}{|l|l|l|l|}
\hline Trait & Exemplary & Satisfactory & Unsatisfactory \\
\hline Technical & $\bullet$ Biological c oncept of & $\bullet$ Biological & $\bullet$ Biological \\
Content & topic covered & concept not & concept \\
& completely & fully covered & lacking \\
& - Good story building & - Average & clarity \\
& - Use of & story & - Role-play \\
& proverbs/contextual & building & context not in \\
& alignment \\
& & & with topic \\
& & & chosen \\
& & & \\
& & & \\
& & & \\
\end{tabular}

Table 4. Rubrics for Assessment: Enacting

\begin{tabular}{|l|l|l|l|}
\hline \multicolumn{1}{|c|}{ Trait } & $\begin{array}{c}\text { Exemplary (65-100 } \\
\mathbf{\%})\end{array}$ & $\begin{array}{l}\text { Satisfactory (34- } \\
\mathbf{6 5 \% )}\end{array}$ & $\begin{array}{c}\text { Unsatisfactory } \\
\mathbf{( 0 - 3 3 \% )}\end{array}$ \\
\hline $\begin{array}{l}\text { Dialogue } \\
\text { delivery }\end{array}$ & $\begin{array}{l}\text { Clarity \& fluency } \\
\text { of speech } \\
\text { team coherence }\end{array}$ & $\begin{array}{l}\text { Average } \\
\text { clarity\& } \\
\text { fluency } \\
\text { Moderate team } \\
\text { coherence }\end{array}$ & $\begin{array}{l}\bullet \text { Lack of clarity } \\
\text { \& fluency } \\
\text { Moderate team } \\
\text { coherence }\end{array}$ \\
\hline $\begin{array}{l}\text { Stage usage } \\
\text { properties/costu } \\
\text { mes }\end{array}$ & $\begin{array}{l}\bullet \text { Optimum use of } \\
\text { stage space, } \\
\text { background } \\
\text { sketches, } \\
\text { aids/costumes }\end{array}$ & Average use & $\begin{array}{l}\bullet \text { Totally lacking } \\
\text { and regardless } \\
\text { of stage and } \\
\text { costume usages. }\end{array}$ \\
\hline
\end{tabular}

D. Response Survey and Questionnare for Role Play CourseActivity

A formal course survey from the student participants was collected to assess the effectiveness and identifying areas with scope for improvement. Following is the model of questionnaire framed for the survey

1). Was Role play a new experience of learning or had practiced earlier?

2). As a participant in Role Play, the understanding of the concept

a). Increased significantlyb). Increased c). Remained same d). Reduced

3). How did the following help in enhancing the learning curve:

口 Technical Script writing:

口 Enacting on stage:

4). The difficulties encountered while:

Writing script and assigning role-
Enacting on stage:

5). The support and guidance of the Course-instructor was:

a). Very goodb). Good. c). Averaged). Poor

6). Suggestions for making the Role Play concept a more effective teaching-learning process:

૫ Marks allotted

口 Time for enacting on stage allotted

口 Interactions of course-instructor-Student groups

( Choice of topics

口 Group formation

a Costumes

7). Any other comment/suggestions regarding the activity for improvement.

A total of twenty four students respondents were chosen randomly for collecting the feedback. The feedback survey showed that it for all the twenty four students, Role Play was a first of a kind of experience as a learning method. Fifteen respondents opined that their understanding of the concept increased significantly, while eight felt it increased and one expressed it remained same. The written and oral communication skills were put to test and helped them in honing the same. Some students felt there was difficulty in story- building appropriate to the topic. Many opined that there was more scope for using properties to enhance the effectiveness. Some respondents expressed their encountered problems in co-ordination of dialogue delivery on stage. A need for hand-holding for writing the scripts by the courseinstructor and a formal rehearsal was felt be few respondents.

Table 5. Students' Response to Role Play as a Pedagogical Tool for Molecular Biology

\begin{tabular}{|l|l|}
\hline Sl. No. & \multicolumn{1}{|c|}{ Response } \\
\hline 1 & It was a new method of learning experience for all the students \\
\hline 2 & $\begin{array}{l}\text { It increased the depth of understanding the concepts played by } \\
\text { them. }\end{array}$ \\
\hline 3 & $\begin{array}{l}\text { Drafting technical script enhanced the writing skills and provided } \\
\text { an opportunity for story-building exercise }\end{array}$ \\
\hline 4 & $\begin{array}{l}\text { Enacting helped them in improving communication skills and } \\
\text { public. } \\
\text { It enabled temporal understanding of the events underlying the } \\
\text { concept }\end{array}$ \\
\hline 5 & $\begin{array}{l}\text { Scope for improvement existed in terms of use of properties and } \\
\text { costumes }\end{array}$ \\
\hline 6 & A need for mock rehearsal was expressed \\
\hline
\end{tabular}




\section{Conclusions:}

The role play was instrumental in enhancing the learning of the concepts and honing the communication skills. It also provided the students with an opportunity to build a story out of a theoretical concept which was hitherto not practiced. The exercise provided the students an opportunity to get engaged in active learning, a way different from traditional approach. The activity instills creative thoughts, motivation to learn and understand team dynamics.

The role-play concept for Molecular Biology course was a overall new experience of teachinglearning process for students and teacher and held scope for improvement for further enhancing its effectiveness in the forthcoming practices.

\section{Acknowledgement:}

The authors thank Dr. Ashok Shettar, Vice Chancellor, Dr. P.G. Tewari, Principal and Prof. B.L. Desai, Registrar, KLE Technological University, Hubballi for their support and encouragement. The authors are thankful to all the student participants for their active involvement and Departmental staff for extending the support.

\section{References:}

[1] Blatner, A. (2000) Foundations of psychodrama: history, theory, and practice. Springer Publishing Company, New-York, 214-230.

[2] Brookfield, S.D. (1987) Developing Critical Thinkers: Challenging Adults to Explore Alternate Ways of Thinking and Acting.
Jossey-Bass, San Francisco

[3] Craciun, D. (2010) Role Plying as a Creative Method in Science Education. Journal of Science and Arts, 1(12), 175-182

[4] deNeve, Kristina M. and Mary J. Heppner.(1997) Role Play Simulations: The Assessment of An Active Learning Technique and Comparisons with Traditional Lectures." Innovative Higher Education 21, 231-246.

[5] Luca, J. and Heal, D. (2006) Using Role-play to Promote Effective Teamwork. Ed-Media. World Conference on Educational Multimedia, Hypermedia \& Telecommunications, Orlando, Florida.

[6] McCaughan, Nano and Tony Scott. (1978) Role Play and Simulation Games: Uses in Social Work Education, National Institute for Social Work, London.

[7] Mitchell, Gordon. (1998) Role-Playing Rhetoric of Science Pedagogy and the Study of Medical Ethics. Paper presented at the Annual Meeting of the National Communication Association, New York, 20-24.

[8] Moore, Vincent. (1995) Using Role Playing in Argument Papers to Deconstruct Stereotypes.Teaching English in the Two Year College, 190-196.

[9] Van der Muelen Rodgers. (1996) A RolePlaying Exercise for Development and International Economics Courses, Journal of Economic Education, 217-223.

[10] http://www.ieagreements.org

[11] http://www.nbaind.org 